\title{
Extraction and Characterization of Passion Fruit and Guava Oils from Industrial Residual Seeds and Their Application as Biofuels
}

\author{
Osvaldo K. Iha, ${ }^{a}$ Guilherme B. C. Martins, ${ }^{a}$ Erick Ehlert, ${ }^{a}$ Mateus A. Montenegro, \\ Renata R. Sucupira ${ }^{a}$ and Paulo A. Z. Suarez $*$,a \\ ${ }^{a} I N C T-C a t a ́ l i s e$, Laboratório de Materiais e Combustíveis, Instituto de Química (IQ), \\ Universidade de Brasília (UnB), Campus Universitário Darcy Ribeiro, \\ P.O. Box 4478, 70904-970 Brasília-DF, Brazil
}

\begin{abstract}
A great diversity of fruits is used in the food industry to obtain different products such as juices, sauces and foods. However, the food industry produces high amounts of residues. Passion fruit and guava are worldwide known fruits and very used by the food industry and generate tons of seed as residue. This work aims to study the extraction of oils from passion fruit and guava juice industries residues, their characterization and potential application as raw materials to obtain biodiesel and bio-oil. The passion fruit and guava seed oils content were 25 and 9\%, respectively. In both oils, polyunsaturated fatty acids are predominant. Biodiesel obtained by esterification/ transesterification of both seed oils match most of the parameters specified for biodiesel in Brazil. Bio-oils obtained by thermal cracking of the seed oils were mainly composed by hydrocarbons similar to those observed in petroleum diesel.
\end{abstract}

Keywords: passion fruit, guava, biofuel, biodiesel, bio-oil

\section{Introduction}

Due to the increasing energy demand and environmental awareness, in the last decades the use of biomass as energy source has been highlighted, especially the application of vegetable and animal fats and oils to produce biodiesel (methyl or ethyl fatty acid esters). The main advantage of biodiesel is its physical-chemical properties, which are similar to those of petroleum derived diesel, permitting their use in diesel engines blended with diesel or alone. ${ }^{1}$ Indeed, biodiesel is one of the most important energetic uses of biomass in this century. For instance, the Brazilian production reached up to 3.19 billion liters of biodiesel in $2017 .^{2}$

However, most of the countries usually use edible oils in the production of biodiesel, such as soybean oil or rapeseed oil, representing the trilemma food-environmentenergy. ${ }^{3}$ For example, in Brazil, in 2015, the main sources of triacylglycerides for biodiesel production were soybean oil $(77.4 \%)$ and beef tallow $(18.5 \%))^{2}$ To address this issue there are several studies involving different alternative raw materials to produce biodiesel, such as: algae oil, coffee

*e-mail: psuarez@unb.br oil, neem oil, chicha oil, "castanhola" fat, andiroba fat and macauba oil. ${ }^{4-9}$

Bio-oils, a biofuel with physical-chemical properties suitable for energetic applications, can also be obtained from fats and oils. This bio-oil is obtained by thermal cracking of fatty materials at high temperatures (above $350{ }^{\circ} \mathrm{C}$ ) in the presence or in the absence of catalysts and is composed mostly of saturated or unsaturated hydrocarbons and carboxylic acids with variable carbon chain length. ${ }^{10}$ Despite its production simplicity and similarity to petroleum derivatives, bio-oil is not regulated as a biofuel in Brazil. However, bio-oil has been extensively studied, mainly from different raw materials, such as vegetable fats and oils like soybean, palm tree and castor bean and other less common seed oils. ${ }^{7-9,11-13}$

The use of fatty materials from residual biomass is well seen as a sustainable alternative for energy production because of the non-competition with food production and the environmental friendly destination of a waste. For instance, studies have been done on the use of fatty material residues from domestic, urban and industrial environments, to produce biodiesel ${ }^{14-18}$ and bio-oil., ${ }^{9,22}$

Under this premise, residues from the juice industry have great potential as raw materials for biofuels due to the vast amount of waste produced by this segment. Passion 
fruit and guava are two of the most used fruits in the Brazilian juice industry. ${ }^{23}$ The waste from the oil extraction is a protein rich bran, which can be used for animal feeding.

Passion fruit needs tropical or subtropical weather to grow and it is produced in several countries, including, in all its extension, Brazil, mainly in the northeast and southeast regions. In 2013, the production of the passion fruit in Brazil was 838,244 tons, distributed in 58,089 ha, leading to a productivity of $14.6 \mathrm{~kg} \mathrm{ha}^{-1}$. The mass of seed waste accounts for 6-12\% of the fruit input, and the oil content of the seeds ranges from 23 up to $30 \%$ (in mass). ${ }^{24}$ The literature ${ }^{23,25-27}$ reports the average carboxylic acid pattern of passion fruit oil as $12-21 \%$ saturated, $18-20 \%$ monounsaturated and $58-69 \%$ of polyunsaturated carboxylic acids, mainly linoleic acid. The main characteristic of passion fruit oil is its elevated acid value and its low oxidative stability, which classifies it as a semi-drying oil.

Like passion fruit, the guava tree can be grown in tropical or sub-tropical regions and it is cultivated in Brazil in the northeast and southeast regions. The production of guava fruit in 2013 was 349,615 tons, distributed in 15,034 ha, leading to the annual productivity of $23.3 \mathrm{~kg} \mathrm{ha}^{-1} .^{24}$ The mass of waste from guava processing accounts for about $30 \%$ of the guava input, and most of this waste are seeds. The literature reports the oil content in guava seeds as about $5-15 \%$ of its mass, with a carboxylic acid pattern of $12 \%$ of saturated, $11 \%$ of monounsaturated and $77 \%$ of polyunsaturated carboxylic acids, being linoleic acid the predominant component as well. Guava oil has low acid value and it is also classified as a semi-drying oil..$^{23}$

The aim of this work is the extraction and characterization of oils from passion fruit and guava seeds obtained from local juice industry as well as the study of their potential use as source to produce biodiesel and bio-oil.

\section{Experimental}

\section{Oil extraction}

The passion fruit and guava seeds were obtained from a fruit processing industry from Goiás State (Midwest region of Brazil). The seeds were washed to remove the organic residues from the fruits, dried at $60{ }^{\circ} \mathrm{C}$, and then triturated using a mill. Their oils were extracted in a Soxhlet apparatus using hexane as solvent for $4 \mathrm{~h}$. The process was repeated three times to estimate the oil content of the seeds. After the extraction, the oil/solvent mixture was treated with $\mathrm{MgSO}_{4}$ to remove the water, and then filtered using $4 \mathrm{~cm}$ celite plug. After this treatment, the solvent was evaporated under reduced pressure in a rotary evaporator.

\section{Biodiesel production}

Because of the high acidity of the oils, the production of methyl fatty acid esters derived from guava and passion fruit crude oils was performed in a glass batch reactor equipped with mechanic stirrer in two steps. First, the vegetable oil, methanol and sulfuric acid (molar ratio of 1:7:0.09, respectively) were kept under gentle reflux for $2 \mathrm{~h}$ and then the reaction mixture was washed three times with a 5\% (mass\%) sodium bicarbonate solution. Thus, the fatty acid methyl esters/oil phase was dissolved in hexane, kept with magnesium sulfate under agitation for $2 \mathrm{~h}$ and then the mixture was filtered and the solvent was removed under vacuum. In the second step, the previous fatty acid methyl esters/oil phase was mixed with a methanolic potassium hydroxide solution (molar ratio of 1:7:0.01 of fatty acid methyl ester/oil, methanol and potassium hydroxide, respectively), under magnetic stirring, for $2 \mathrm{~h}$ at room temperature. Then, the mixture was allowed to rest, and two phases were obtained (one phase containing fatty acid methyl esters and the other containing glycerin, potassium hydroxide, and methanol). The residual methanol in the fatty acid methyl esters phase was removed by rotary evaporation at $70{ }^{\circ} \mathrm{C}$. The fatty acid methyl esters were washed with phosphoric acid (5\% v/v) and then brine, dissolved in hexane, dried with magnesium sulfate for $2 \mathrm{~h}$, filtered and, finally, the volatiles were removed under vacuum. The second step was repeated two more times until purity of more than 98 mass $\%$ in fatty acid methyl esters was detected by high performance liquid chromatography (HPLC), using the method described in the literature. ${ }^{28}$ The methyl esters were stored in amber flasks inside a freezer.

\section{Bio-oil production}

The pyrolysis of guava and passion fruit crude oils $(250 \mathrm{~g})$ were carried out in a three-necked flask connected with a condensation system, as described elsewhere. ${ }^{22}$ The oil was heated to $380{ }^{\circ} \mathrm{C}$ (the temperature was measured by thermocouples throughout the reaction bulk) and the cracking reaction products that leaved the round flask as vapors were condensed to obtain a two-phase system, consisting of an aqueous phase and the bio-oil. The yields in bio-oil were around $60 \%$.

\section{Biofuels analysis}

The physical-chemical analysis of the biofuels were conducted based on the following standard methods: kinematic viscosity (ASTM D445), flash point (ASTM D93), copper corrosion (ASTM D130), density at $20{ }^{\circ} \mathrm{C}$ 
(NBR 7148), carbon residue (ASTM D189), cold filter plugging point (ASTM D6371), acidity index (AOCS Cd3d63), and calorific capacity (ASTM D240).

Biodiesels were analyzed by HPLC using a Shimadzu equipment, model CTO 20A, coupled with a UV-Vis detector set at the wavelength of $205 \mathrm{~nm}$, according to a method published elsewhere. ${ }^{28}$ The column used in the analysis was a Shim-Pack VP-ODS model, with $18 \mathrm{~cm}$ of length, $250 \mathrm{~mm}$ of external diameter and $4.6 \mathrm{~mm}$ of internal diameter. The injected volume was $20 \mu \mathrm{L}$ using a solvent flux rate of $1 \mathrm{~mL} \mathrm{~min}^{-1}$ and the temperature of the column was kept at $40{ }^{\circ} \mathrm{C}$. The samples were dissolved in a propanol/hexane $(5: 4 \mathrm{v} / \mathrm{v})$ solution and injected directly in the column. After the injection, a binary gradient of 20 min was applied: $100 \%$ methanol until the first $10 \mathrm{~min}$ and then $50 \%$ of methanol and $50 \%$ of a solution of 2-propanol/hexane $(5: 4 \mathrm{v} / \mathrm{v})$ for the last $10 \mathrm{~min}$, totalizing $20 \mathrm{~min}$ of analysis.

Nuclear magnetic resonance $\left({ }^{1} \mathrm{H}\right.$ NMR) data was acquired in an equipment from Anasazi Instruments Inc., model Eft-60 of $60 \mathrm{MHz}$. NMR technique was used for the quantification of the biodiesel obtained, based on the chemical shift $(\delta$ ) of the fatty acid methyl esters hydrogens. For ${ }^{1} \mathrm{H}$ NMR analyses, it was used TMS (tetramethylsilane) as internal reference, using $0.5 \mathrm{~mL}$ of sample, no solvent was used. For the quantification of biodiesel, the area of the methoxy group (3.67 ppm, singlet) was related to the area of the olefinic hydrogens of the alkyl chains (5.46-5.27 ppm, multiplet).

The bio-oil samples were analyzed by gas chromatography coupled with a mass spectrometer (GC-MS), using a Shimadzu equipment model GC-MS-QP5050 with a capillary column of melted silicate CBPI PONA with a length of $50 \mathrm{~m}, 0.15 \mu \mathrm{m}$ of diameter and $0.42 \mu \mathrm{m}$ of thickness. The injection temperature was $250{ }^{\circ} \mathrm{C}$, a He flux of $0.7 \mathrm{~mL} \mathrm{~min}^{-1}$, and a temperature ramp from 60 to $250{ }^{\circ} \mathrm{C}$ with a $10^{\circ} \mathrm{C} \mathrm{min}{ }^{-1}$ heating rate, totalizing a run time of $39 \mathrm{~min}$. The crude bio-oil composition was determined using Wiley $6^{\text {th }}$ edition for Class-5000 mass spectral library. The percentage of the compounds were calculated using the GCMS Post run analysis software version 1.02 from Shimadzu by the areas of the peaks.

\section{Results and Discussion}

\section{Crude oil extraction and characterization}

Crude oil contents in passion fruit (PF) and guava (G) were found to be, respectively, 25 and 9\%, which are in good accordance with the values published in the literature. ${ }^{23-29}$ There are few reports in the literature ${ }^{26-30}$ about the characterization of these oils and these studies point out that the three major fatty acids in both $\mathrm{G}$ and $\mathrm{PF}$ are linoleic (from 35 to $77 \%$ ), oleic (from 10 to 20\%) and palmitic (from 10 to $35 \%$ ) acids. It is important to highlight that the different values observed in the literature may be explained due to differences in the species and cultivars studied, as well as edaphoclimatic conditions. The fatty acid compositions of the crude oils obtained in this study are depicted in Table 1. According to Table 1, the major components of both PF and $\mathrm{G}$ are, indeed, these three fatty acids. It is worth to mention that the composition observed in the present study was very close to those related for soybean oil, except for the very low linolenic acid content $(<1 \%)$.

Table 1. Fatty acid composition of PF and G oils

\begin{tabular}{lcc}
\hline Fatty acid & PF & G \\
\hline C16:0 (palmitic) & 14 & 7 \\
C18:0 (stearic) & 7 & 16 \\
C18:1 (oleic) & 20 & 9 \\
C18:2 cis/cis 9,12 (linoleic) & 50 & 52 \\
C18:3 cis/cis/cis 9,12,15 (linolenic) & 1 & $>1$ \\
Others & 8 & ca. 16 \\
Saturated chains / \% & 21 & 23 \\
Monounsaturated chains / \% & 20 & 9 \\
Polyunsaturated chains / \% & 51 & 52 \\
\hline
\end{tabular}

PF: passion fruit; G: guava.

The physical-chemical properties of the obtained crude oils are depicted in Table 2. Passion fruit oil presented elevated acidity when compared to the values observed in the literature, ${ }^{23,25,26}$ which indicates a great amount of free fatty acids. A possible explanation is the difference in the seed preparation. Indeed, as described in the Experimental section, the seeds used in this study are residues from industrial processing, thus it is possible that during the processing or the storage of the fruits the triacylglycerides suffered hydrolysis and turned into fatty acids. On the other hand, guava oil has shown low acidity. The oxidation stability analysis shows a higher induction time for guava crude oil when compared to passion fruit crude oil. The lower stability of passion fruit crude oil can be associated to its higher monounsaturated chains and also to its higher acid value.

Table 2. Physical-chemical properties of the crude oil extracted from passion fruit and guava seeds

\begin{tabular}{lcc}
\hline & Passion fruit & Guava \\
\hline Acidity index / (mg KOH g-1) & 103 & 1.2 \\
Oxidation stability / h & 1.25 & 4.0 \\
Calorific capacity / $\left(\mathrm{MJ} \mathrm{kg}^{-1}\right)$ & 40.3 & 38.0 \\
Kinematic viscosity at $40^{\circ} \mathrm{C} / \mathrm{cSt}$ & 22.5 & 28.8 \\
Density at $20^{\circ} \mathrm{C} /\left(\mathrm{kg} \mathrm{m}^{-3}\right)$ & 907 & 919 \\
\hline
\end{tabular}


As described in Table 2, guava oil is approximately $20 \%$ more viscous than passion fruit oil. The higher viscosity of guava oil is expected because of its lower value of acidity index, which means that it possess less free fatty acids and, thus, more triacylglycerides in its composition, having a higher average molecular mass which leads to a higher viscosity. A similar behavior for the density was observed. Whatsoever, passion fruit oil is more energetic than guava oil as can be observed by the calorific capacity of both crude oils.

HPLC chromatograms of crude passion fruit and guava oils are shown in Figure 1. The peaks at 5 min of retention time are related to free fatty acids and monoacylglycerides. In the passion fruit chromatogram it is possible to identify a large amount of free fatty acids, which confirms the acidity index analysis. The peaks close to the retention time of $10 \mathrm{~min}$ are related to diacylglycerides and the ones above $15 \mathrm{~min}$ are related to the triacylglycerides of the crude oils.

\section{Biofuels analysis}

The biodiesel purity was measured by HPLC and NMR techniques. In the guava HPLC chromatogram (Figure 1) it is possible to observe a severe decrease in the peaks

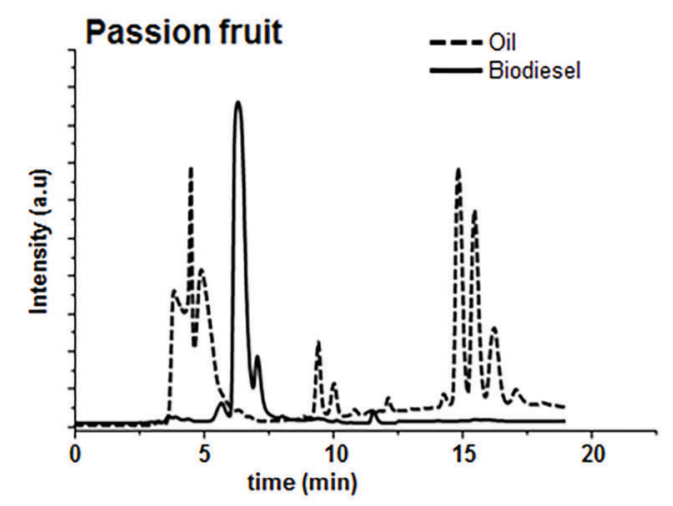

related to acylglicerydes, evidencing the consumption of the starting material, and the appearance of peaks between 6 and 7 min, related to methyl esters. The high acidity of passion fruit oil required a preliminary esterification step to be performed to avoid the formation of soap during the transesterification step. In Figure 1, it is possible to see the disappearance of peaks related to free fatty acids and the increasing of the area of peaks related to methyl esters. In sequence, a transesterification was carried out in the esterified oil in order to transform the acylglycerides in methyl esters. The ${ }^{1} \mathrm{H}$ NMR spectra of the final products can be depicted in Figure 2. It is possible to see a singlet at $3.67 \mathrm{ppm}$, which correspond to the hydrogens of the methoxy group from the formed ester. ${ }^{1} \mathrm{H}$ NMR analysis indicates a 99\% pure biodiesel in both passion and guava after the transesterification step.

The physical-chemical characterization of the obtained products can be observed in Table 3. Both methyl ester mixtures meet most of the specifications for biodiesel. Data such as the cold filter plunging point and the viscosity of the biofuels indicate that they can be used in all the Brazilian territory without seasonal restrictions. The adequacy of both biofuels to the Brazilian biodiesel requirements were expected since the composition of both passion fruit and

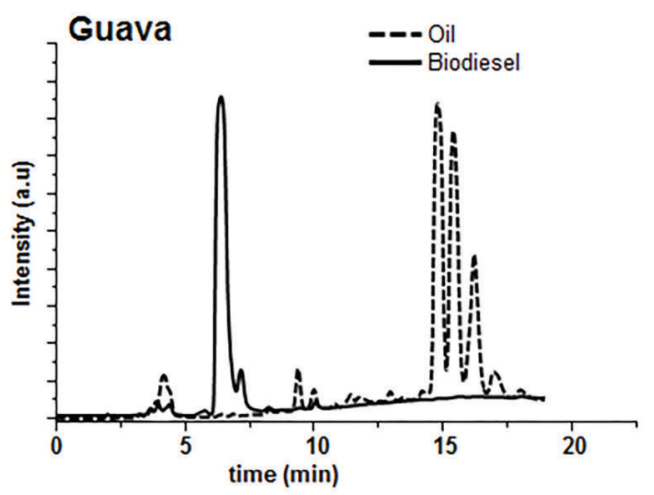

Figure 1. HPLC-UV chromatograms of passion fruit and guava crude oils and their biodiesel.
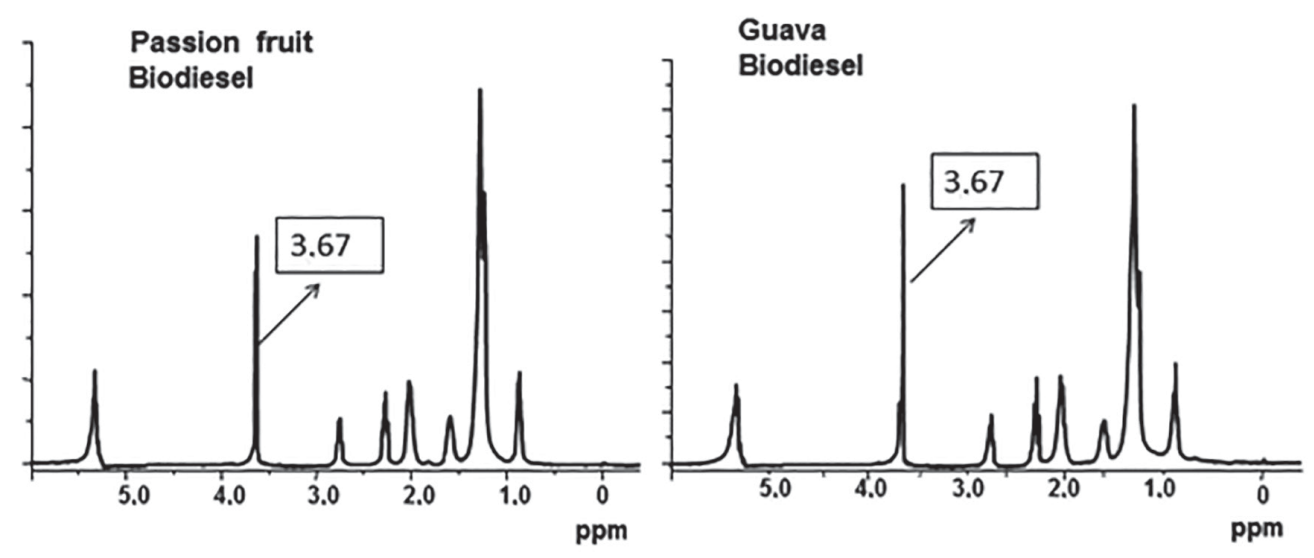

Figure 2. ${ }^{1} \mathrm{H}$ NMR spectra (60 MHz, no solvents used) of passion fruit and guava transesterification products. 
Table 3. Physical-chemical properties of biodiesels obtained from passion fruit and guava oils

\begin{tabular}{lccc}
\hline & Passion fruit biodiesel & Guava biodiesel & Biodiesel $^{\mathrm{a}}$ \\
\hline Acidity index $/\left(\mathrm{mgKOH} \mathrm{g}^{-1}\right)$ & $>1.0$ & $>1.0$ & 0.5 \\
Cold filter plunging point $/{ }^{\circ} \mathrm{C}$ & -4 & -3 & 7 \\
Calorific power $/\left(\mathrm{MJ} \mathrm{kg}^{-1}\right)$ & 40.25 & 41.17 & - \\
Kinematic viscosity at $40{ }^{\circ} \mathrm{C} / \mathrm{cSt}$ & 3.81 & 4.09 & $3-6$ \\
Density at $20^{\circ} \mathrm{C} /\left(\mathrm{kg} \mathrm{m}^{-3}\right)$ & 882 & 882 & $850-900$ \\
Carbon residue $/ \%$ & 0.2 & 0.18 & 0.05 \\
Flash point $/{ }^{\circ} \mathrm{C}$ & 183 & 173 & 100 \\
Copper corrosion & $1 \mathrm{a}$ & $1 \mathrm{a}$ & $1 \mathrm{a}$ \\
\hline
\end{tabular}

aLimit values specified for biodiesel according to Agência Nacional do Petróleo, Gás Natural e Biocombustíveis (ANP), Resolution No. 14. ${ }^{31}$ 1a: value measured by the ASTM D130 method.

guava oils are very similar to soybean oil, which is the predominant oil used in Brazil for biodiesel production. ${ }^{25}$

The cracking reactions revealed that the thermal decomposition of the oils began at $350{ }^{\circ} \mathrm{C}$, for guava, and at $320^{\circ} \mathrm{C}$, for passion fruit. The difference in the reactivity of both oils may be related to their different content of free fatty acids. Indeed, free fatty acids do thermally decompose before triacylglycerides. Table 4 presents the mass balance for the cracking reactions. At the end of the reaction, two phases were obtained, an organic phase, which is called bio-oil, and an aqueous phase, composed by water and other polar compounds. Both phases were separated by decantation. The part of the oil that did not distillate and remained in the flask is a biopolymer, which can be used as bind for printing inks formulations. ${ }^{32}$

Both bio-oils are similar in composition, as can be noticed by the GC chromatogram in Figure 3 . The large peaks represent carboxylic acids, saturated and unsaturated hydrocarbons, with different length in their alkyl chains. The lower peaks are related to oxygenated compounds produced by the decomposition of the glycerol fragment.

According to Table 5, both bio-oils have similar chemical composition, although passion fruit bio-oil has a higher amount of compounds with more than 15 carbons in their chain. Passion fruit bio-oil also shows a lower carboxylic acid content, even though it has a higher acidity

Table 4. Mass balance of thermal cracking reactions of the passion fruit and guava crude oils

\begin{tabular}{lcccc}
\hline & Non-distilled & Organic phase & Aqueous phase & Gas loss \\
\hline Passion fruit $/(\% \mathrm{~m} / \mathrm{m})$ & 17.1 & 74.9 & 2.0 & 6.0 \\
Guava / $(\% \mathrm{~m} / \mathrm{m})$ & 22.8 & 66.0 & 1.2 & 10.0 \\
\hline
\end{tabular}
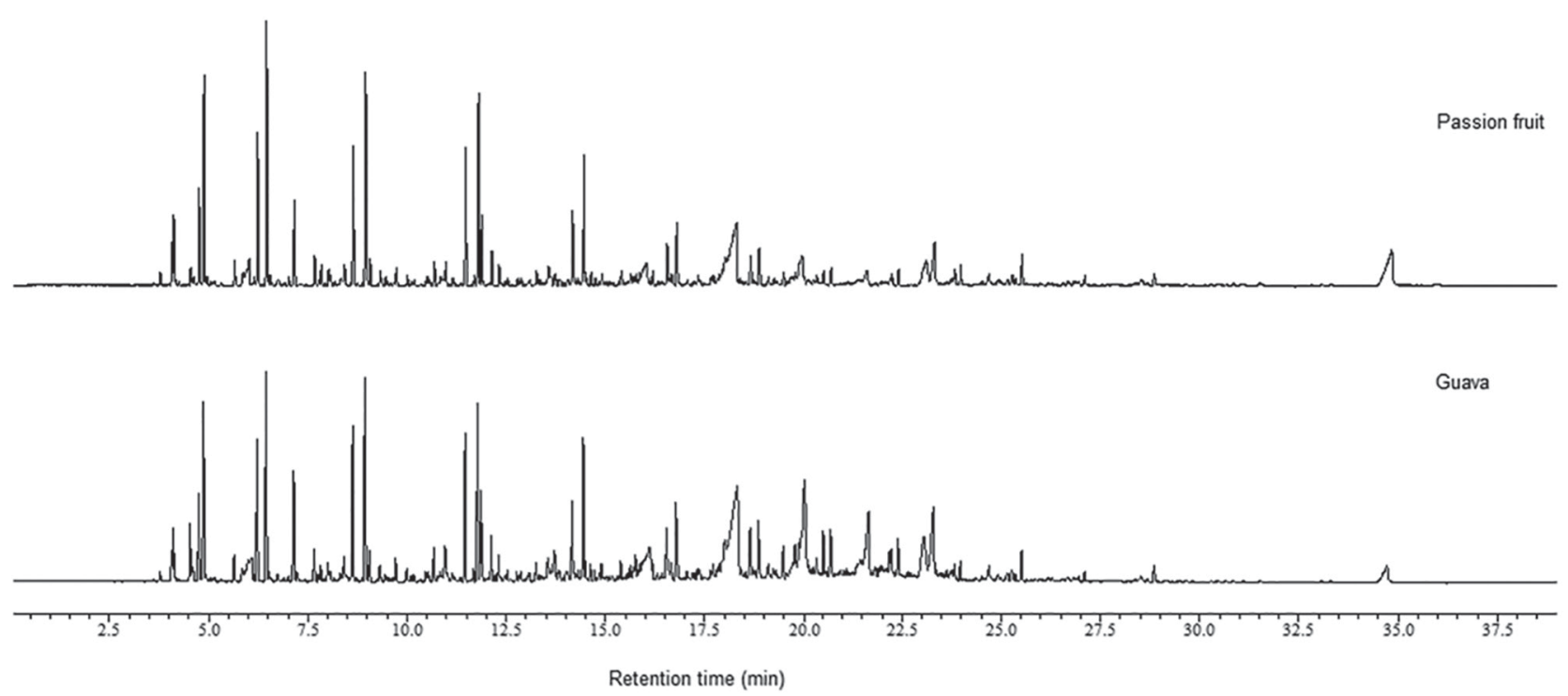

Figure 3. GC-MS chromatograms of bio-oils obtained from thermal decomposition of passion fruit and guava crude oils. 
index value, according to Table 6. Passion fruit crude oil has more free fatty acids in its composition, which can be directly be distilled without cracking during the reaction. Anyway, it is possible to see that carboxylic acids account for more than $30 \%$ of the composition of both bio-oils, which justifies the large values of acidity measured. Thus, these bio-oils cannot be used as diesel-like fuels without a previous deoxygenating treatment. However, in order to obtain a lower oxygen content in the bio-oils, the cracking of $\mathrm{G}$ and PF oils may also be performed in the presence of a specific catalyst or by changing the reaction conditions, such as using higher temperatures or hydrogen pressure, as previously published for other raw materials. ${ }^{33,34}$

Table 5. Approximated percentage of the compounds presents in the bio-oils obtained by thermal cracking of passion fruit and guava crude oil

\begin{tabular}{lcc}
\hline & Passion fruit & Guava \\
\hline Carboxylic acids / $\%$ & 26 & 32 \\
$<\mathrm{C}_{5} / \%$ & 5 & 4 \\
$\mathrm{C}_{5}-\mathrm{C}_{10} / \%$ & 73 & 73 \\
$\mathrm{C}_{11}-\mathrm{C}_{15} / \%$ & 15 & 20 \\
$>\mathrm{C}_{15} / \%$ & 7 & 3 \\
\hline
\end{tabular}

Table 6. Physical-chemical properties of the bio-oil obtained from passion fruit and guava oils

\begin{tabular}{|c|c|c|c|}
\hline & & Passion fruit & Guava \\
\hline Acidity index / (mg KOH g $\left.{ }^{-1}\right)$ & & 154.6 & 134.7 \\
\hline Cold filter plunging point $/{ }^{\circ} \mathrm{C}$ & & 15 & 10 \\
\hline Calorific power / $\left(\mathrm{MJ} \mathrm{kg}^{-1}\right)$ & & 36.95 & 35.20 \\
\hline Kinematic viscosity at $40^{\circ} \mathrm{C} / \mathrm{cSt}$ & & 7.17 & 4.69 \\
\hline Density at $20^{\circ} \mathrm{C} /\left(\mathrm{kg} \mathrm{m}^{-3}\right)$ & & 874 & 868 \\
\hline Carbon residue / \% & & 0.58 & 0.65 \\
\hline Flash point $/{ }^{\circ} \mathrm{C}$ & & 83 & 43 \\
\hline Copper corrosion & & $1 \mathrm{a}$ & $1 \mathrm{a}$ \\
\hline \multirow{3}{*}{ Automatic distillation $/{ }^{\circ} \mathrm{C}$} & $10 \%$ & 216.0 & 186.1 \\
\hline & $50 \%$ & 337.1 & 331.3 \\
\hline & $90 \%$ & 345.8 & 328.1 \\
\hline
\end{tabular}

1a: value measured by the ASTM D130 method.

It is also possible to see in Table 6 that PF bio-oil is denser and more viscous than guava bio-oil, which is likely due to the higher quantity of hydrocarbons longer than $\mathrm{C}_{15}$, which is also observed in the flash point and distillation analyses. In addition, the calorific power values of bio-oils are lower if compared to the respective biodiesels (Table 3), probably because of the higher amount of oxygen in the composition of the bio-oils. According to automatic distillation data, both bio-oils would require further treatment in order to be used as diesel-like fuels.

\section{Conclusions}

Passion fruit and guava seeds are residues produced in large scale by the food industry. We have shown that it is possible to extract oils from both residues and use them for biofuels production. The biodiesel obtained from both oils match the specified parameters for this biofuel in Brazil. However, the bio-oils from both seeds need further treatment to remove oxygenated and light compounds and, thus, be suitable to be used as diesel-like biofuel.

\section{Acknowledgments}

The authors are thankful to FAP-DF and CAPES for financial support. The authors wish also to thank CNPq for research fellowships.

\section{References}

1. Suarez, P. A. Z.; Santos, A. L. F.; Rodrigues, J. P.; Alves, M. B.; Quim. Nova 2009, 32, 768.

2. http://www.brasil.gov.br/infraestrutura/2017/01/producao-debiodiesel-atinge-recorde-de-351-mil-metros-cubicos, accessed in April 2018.

3. Tilman, D.; Socolow, R.; Foley, J. A.; Hill, J.; Larson, E.; Lynd, L.; Pacala, S.; Reilly, J.; Searchinger, T.; Somerville, C.; Williams, R.; Science 2009, 325, 270.

4. Nautiyal, P.; Subramanian, K. A.; Dastidar, M. G.; Fuel Process. Technol. 2014, 120, 79.

5. Vardon, D. R.; Moser, B. R.; Zheng, W.; Witkin, K.; Evangelista, R. L.; Strathmann, T. J.; Rajagopalan, K.; Sharma, B. K.; ACS Sustainable Chem. Eng. 2013, 1, 1286.

6. Ali, M. H.; Mashud, M.; Rubel, M. R.; Ahmad, R. H.; Procedia Eng. 2013, 56, 625.

7. Mangas, M. B. P.; Rocha, F. N.; Suarez, P. A. Z.; Meneghetti, S. M. P.; Barbosa, D. C.; Santos, R. B.; Carvalho, S. H. V.; Soletti, J. I.; Ind. Crops Prod. 2012, 36, 349.

8. Iha, O. K.; Alves, F. C. S. C.; Suarez, P. A. Z.; Silva, C. R. P.; Meneghetti, M. R.; Meneghetti, S. M. P.; Ind. Crops Prod. 2014, 52,95 .

9. Iha, O. K.; Alves, F. C. S. C.; Suarez, P. A. Z.; Oliveira, M. B. F.; Meneghetti, S. M. P.; Santos, B. P. T.; Soletti, J. I.; Ind. Crops Prod. 2014, 62, 318.

10. Martins, G. B. C.; Mello, V. M.; Suarez, P. A. Z.; Rev. Virtual Quim. 2013, 5, 16.

11. Lima, D. G.; Soares, V. C. D.; Ribeiro, E. B.; Carvalho, D. A.; Cardoso, E. C. V.; Rassi, F. C.; Mundim, K. C.; Rubim, J. C.; Suarez, P. A. Z.; J. Anal. Appl. Pyrolysis 2009, 71, 987.

12. Prado, C. M. R.; Filho, N. R. A.; J. Anal. Appl. Pyrolysis 2009, $86,388$. 
13. Fortes, I. C. P.; Baugh, P. J.; J. Anal. Appl. Pyrolysis 2004, 72, 103.

14. Hamamre, Z.-A.; Yamin, J.; Energy Convers. Manage. 2014, $79,246$.

15. Canesin, E. A.; Oliveira, C. C.; Matsushita, M.; Dias, L. F.; Pedrão, M. R.; Souza, N. E.; Electron. J. Biotechnol. 2014, 17, 39.

16. Andersen, O.; Weinbach, J.-E.; Biomass Bioenergy 2010, 34, 1183.

17. Banković-Ilić, I. B.; Stojković, I. J.; Stamenković, O. S.; Veljkovic, V. B.; Hung, Y.-T.; Renewable Sustainable Energy Rev. 2014, 32, 238.

18. García-Moreno, P. J.; Khanum, M.; Guadix, A.; Guadix, E. M.; Renewable Energy 2014, 68, 618.

19. Lappi, H.; Alén, R.; J. Anal. Appl. Pyrolysis 2011, 91, 154.

20. Nam, L. T. H.; Vinh, T. Q.; Loan, N. T. T.; Tho, V. D. S.; Yang, X.-Y.; Su, B.-L.; Fuel 2011, 90, 1069.

21. Bezergianni, S.; Kalogianni, A.; Bioresour. Technol. 2009, 100, 3927.

22. Santos, A. L. F.; Martins, D. U.; Iha, O. K.; Ribeiro, R. A. M.; Quirino, R. L.; Suarez, P. A.Z.; Bioresour. Technol. 2010, 101, 6157.

23. Kobori, C. N.; Jorge, N.; Ciênc. Agrotec. 2005, 29, 1008.

24. ftp://ftp.ibge.gov.br/Producao_Agricola/Producao_Agricola_ Municipal_[anual]/2013/pam2013.pdf, accessed in April 2018.

25. Ferrari R. A.; Colussi, F.; Ayub, R. A.; Rev. Bras. Fruticultura 2004, 26, 101.

26. Malacrida, C. R.; Jorge, N.; Braz. Arch. Biol. Technol. 2012, $55,127$.
27. Oliveira, R. C.; Barros, S. T. D.; Gimenes, M. L.; J. Food Eng. 2013, 117, 458.

28. Carvalho, M. S.; Mendonça, M. A.; Pinho, D. M. M.; Resck, I.; Suarez, P. A. Z.; J. Braz. Chem. Soc. 2012, 23, 763.

29. Piombo, G.; Barouh, N.; Barea, B.; Boulanger, R.; Brat, P.; Pina, M.; Villeneuve, P.; Ol., Corps Gras, Lipides 2006, 13, 195.

30. Uchoa-Thomaz, A. M. A.; Sousa, E. C.; Carioca, J. O. B.; Morais, S. M.; de Lima, A.; Martins, C. G.; Alexandrino, C. D.; Ferreira, P. A. T.; Rodrigues, A. L. M.; Rodrigues, S. P.; Thomaz, J. C. A.; Silva, J. N.; Rodrigues, L. L.; Food Sci. Technol. (Campinas) 2014, 34, 485.

31. Agência Nacional do Petróleo, Gás Natural e Biocombustíveis (ANP); Resolução ANP No. 14, de 11/05/2012, Diário Oficial da União (DOU) 18/05/2012, No. 96, Seção 1, p. 79. Available at https://www.jusbrasil.com.br/diarios/37093967/dou-secao-118-05-2012-pg-79, accessed in April 2018.

32. Mello, V. M.; Martins, G. B. C.; Montenegro, M. A.; Suarez, P. A. Z.; Ind. Crops Prod. 2015, 66, 255.

33. Quirino, R. L.; Tavares, A. P.; Peres, A. C.; Rubim, J. C.; Suarez, P. A. Z.; J. Am. Oil Chem. Soc. 2009, 86, 167.

34. Rodrigues, J. P.; Jacinto, M. J.; Oliveira, H. L.; Falcão, Y. O.; Suarez, P. A. Z.; Rossi, L. M.; J. Am. Oil Chem. Soc. 2014, 25, 2364.

Submitted: June 11, 2017 Published online: April 17, 2018 